\title{
PERAN KEPROTOKOLAN DALAM MENERIMA KUNJUNGAN KERJA DARI INSTANSI DI LINGKUNGAN SEKRETARIAT DPRD KOTA TANGERANG SELATAN
}

\author{
Oleh: \\ Dra. Ratna Suminar,MM \\ Dosen Sekretari Universitas Pamulang \\ dan \\ Katrina Tobing \\ Mahasiswi Sekretari Universitas Pamulang
}

\begin{abstract}
ABSTRAK
Katrina Tobing Nim 2011130024 Judul Tugas Akhir Peran Keprotokolan dalam menerima kunjungan kerja dari Instansi di lingkungan Sekretariat DPRD Kota Tangerang Selatan. Laporan Tugas Akhir Program Studi Sekretari D III Fakultas Ekonomi Universitas Pamulang 2014. Keprotokolan sangat berperan penting dalam suatu Instansi/Organisasi, serta berhasil atau tidaknya suatu acara. Keprotokolan juga memegang peranan untuk memfasilitasi kinerja Dewan, sehingga Dewan dapat melaksanakan tugas dan wewenangnya dengan baik serta membantu mengingatkan atau memberitahukan jadwal kegiatannya dan mengundang Dewan untuk menghadiri semua kegiatan yang terkait dengan Dewan. Praktek Kerja Lapangan Ini Dilakukan Pada Sekretariat DPRD Kota tangerang selatan. Untuk mengetahui bagaimana peran seorang Keprotokolan dalam menerima tamu. Tamu yang sering datang biasanya ialah tamu Kunjungan kerja dari instansi/organisasi. Dalam Kunjungan kerja terdapat beberapa pembahasan, tergantung Dewan/Komisi yang akan menerima Tamu Kunjungan kerja tersebut. Komisi I : pemerintahan, komisi II : Pendidikan, Komisi III : Anggaran dan Komisi IV : Bina Marga. Dalam menerima Tamu, keprotokolan sudah harus mempersiapkan Ruangan yang dipakai,alat-alat yang digunakan,materi yang akan dibahas serta konsumsi.
\end{abstract}

\section{A. Pendahuluan}

Pimpinan dan Anggota Dewan memiliki cukup padat kegiatan untuk menunjang hak dan kewajibannya sebagai Dewan yang dipilih langsung oleh rakyat untuk mewakili aspirasi rakyat. Selain itu sebagai pengabdian kepada rakyat dengan menjalankan seluruh tugas dan wewenang yang telah ditetapkan. Dengan kegiatan yang cukup padat tidak mungkin Pimpinan dan Anggota Dewan dapat mengatasi sendiri jadwal kegiatan yang akan dilakukannya.

Maka dari itu Dewan membutuhkan peranan orang lain untuk membantu mengingatkan atau memberitahukan jadwal kegiatannya dan mengundang Dewan untuk menghadiri semua kegiatan yang terkait dengan Dewan, dalam hal ini Sekretariat Dewan 
yang didalamnya terdapat bagian Keprotokolan memegang peranan untuk memfasilitasi kinerja Dewan sehingga Dewan dapat melaksanakan tugas dan wewenangnya dengan baik.

Secara estimologis (dalam buku Sejarah dan Fungsi Keprotokolan oleh Rosita Wiryandari) istilah protocol dalam bahasa Inggris protocol, bahasa Perancis protocole, bahasa Latin protocoll(um) dan bahasa Yunani protocollon. Dalam kamus Bahasa Inggris Oxford, awalnya, istilah protokol berarti halaman pertama yang dilekatkan pada sebuah manuskrip atau naskah. Sejalan dengan perkembangan jaman, pengertiannya berkembang semakin luas tidak hanya sekedar halaman pertama dari suatu naskah, melainkan keselurahan naskah yang isinya terdiri dari catatan, dokumen persetujuan, perjanjian, dan lain-lain dalam lingkup secara nasional maupun internasional.

Perkembangan selanjutnya, protokol berarti kebiasan-kebiasan dan peraturanperaturan yang berkaitan dengan formalitas, tata urutan dan etiket diplomatik. Masalah protokoler ditujukan pada keberhasilan pelaksanaan suatu kegiatan dan pada hal-hal yang mengatur seluruh manusia yang terlibat dalam pelaksanaan suatu kegiatan. Suatu kegiatan apapun pada dasarnya merupakan pelaksanaan dari hasil kerja tahapan-tahapan sebelumnya.

Dalam Rapat Kerja Nasional-Rakernas Protokol tanggal 7-9 Maret 2004 di Jakarta disepakati keprotokolan adalah "Norma-norma atau aturan-aturan atau kebiasaan yang dianut atau diyakini dalam kehidupan bernegara, berbangsa, pemerintah dan masyarakat.". Keprotokolan di Indonesia diatur dalam Undang-undang nomor 8 tahun 1987, ialah serangkaian aturan dalam acara kenegaraan atau acara resmi yang meliputi aturan mengenai tata tempat, tata upacara dan tata penghormatan kepada seseorang sesuai dengan jabatan atau kedudukannya dalam negara, pemerintahan atau masyarakat.

Dilingkungan Sekretariat DPRD kota Tangerang Selatan yang mengatur kegiatan protokol adalah pejabat protokol yang berkompenten dalam menyelenggarakan keprotokolan dan seseorang yang memiliki tugas dan fungsi yang berkaitan dengan keprotokolan.

\section{B. Landasan Teori}

\section{Pengertian Keprotokolan}

Protokol berasal dari kata Yunani, protos dan kolla artinya yang pertama yang dilekatkan. Menurut Max dalam bukunya, dasar-dasar Protokol Etiket dan hubungan antara manusia arti Protokol sesungguhnya ialah Lembaran pertama yang dilekatkan pada dokumen utama. Kemudian dokumen-dokumen yang berisi kesimpulan-kesimpulan itu disebut Protokol. 


\section{Tugas dan Persyaratan pelaksanaan Keprotokolan}

Keprotokolan sangat penting sekali di dalam mengatur hubungan pergaulan antar individu di dalam organisasi atau bangsa, hal yang harus dipersiapkan oleh seorang tugas seksi protokol ialah : Menetapkan urutan atau susunan acara atau agenda pertemuan sehingga diketahui waktu yang diperlukan, Menentukan siapa yang bertugas menjadi pembawa cara atau MC (Master of Ceremony), Menetapkan tamu yang diundanng, Menentukan orang yang ditugaskan untuk melakukan dan bertanggung jawab atas masing-maing pekerja, misalnya : Urusan tata ruang atau panggung, Urusan dekorasi, Urusan penerima tamu, Urusan mencetak dan menyebarluaskan undangan, Urusan perlengkapan teknis, yaitu pengeras suara dan penerangan. Urusan Tv, juru kamera, Urusan kendaraan dengan sopirnya, Urusan keamanan, Urusan konsumsi.

\section{Pengertian Penerimaan Tamu}

Salah satu pekerjaan rutin dalam kantor adalah menerima tamu yang ingin bertemu dengan pejabat tertentu. Para tamu akan mendapat kesan pertama tentang suatu kantor pada saat ia bertemu. Oleh karena itu, petugas atau karyawan yang akan menerima tamu harus bersikap sopan, ramah, bijaksana dan yang penting penerima tamu harus memmpunyai pengetahuan tentang organisasi/instansi dimana dia bekerja. Hal yang harus diperhatikan dalam menerima Tamu ialah : Menata Ruang Tamu, Jenis dan Maksud kedatangan Tamu, Tata cara penerimaan Tamu, Tata cara pengaturan tempat duduk dan kesalahan dalam menerima tamu.

\section{Pembahasan dan Hasil}

\section{Sejarah DPRD Kota Tangerang Selatan}

Pada masa penjajahan belanda, wilayah ini masuk kedalam karasidenan batavia dan mempertahankan karakteristik tiga etnis yaitu suku sunda, suku betawi, dan tionghoa. Pada tanggal 27 desember 2006 terbentuknya kota tangerang yang disetujui oleh DPRD, kota otonom ini terdiri atas tujuh kecamatan yakni ciputat, ciputat timur, pamulang, pondok aren, serpong, serpong utara dan setu. Kecamatan ciputat ditetapkan sebagai pusat pemerintahann kota tangerang selatan oleh ketua DPRD endang sujana pada tanggal 22 januari 2007.

\section{Visi dan Misi}

Pada sekretariat DPRD Tangerang Selatan memiliki tujuan dan komitmen untuk lebih meningkatkan aktifitas agar lebih baik kedepanya untuk mencapai semua itu membutuhkan dorongan maka terbentuknya visi menjadikan dewan perwakilan daerah sebagai lembaga perwakilan rakyat terpercaya, kreatif dan produktif dan juga mempunyai 
misi yaitu menyelenggarakan fungsi legislatif secara proaktif untuk kepentingan masyarakat, meyelenggarakan fungsi anggaran dengan berorientasi pada pengalokasian anggaran daerah untuk pemenuhan kebutuhan dasar masyarakat, menyelenggarakan funsgsi pengawasan secara bertanggung jawab dan meningkatkan kelembangaan dewan perwakilan rakyat daerah dalam menjalankan tugas, fungsi, wewenang, dan kewajiban lembaga dan anggota DPRD.

\section{Sruktur Organisasi}

Pengorganisasian merupakan susunan atau hubungan antara tiap bagian atau posisi yang ada pada suatu organisasi atau perusahan yang menjalakan kegiatan operasional untuk mencapai tujuan yang diharapkan atau yang diinginkan, dan juga menggambarkan dengan jelas tentang tugas dan tanggung jawab dalam melaksanakan pekerjaan dan bagaimana hubungan aktifitas dan hubungan yang dibatasi.

\section{Struktur organisasi sekretariat DPRD Kota Tangerang Selatan}

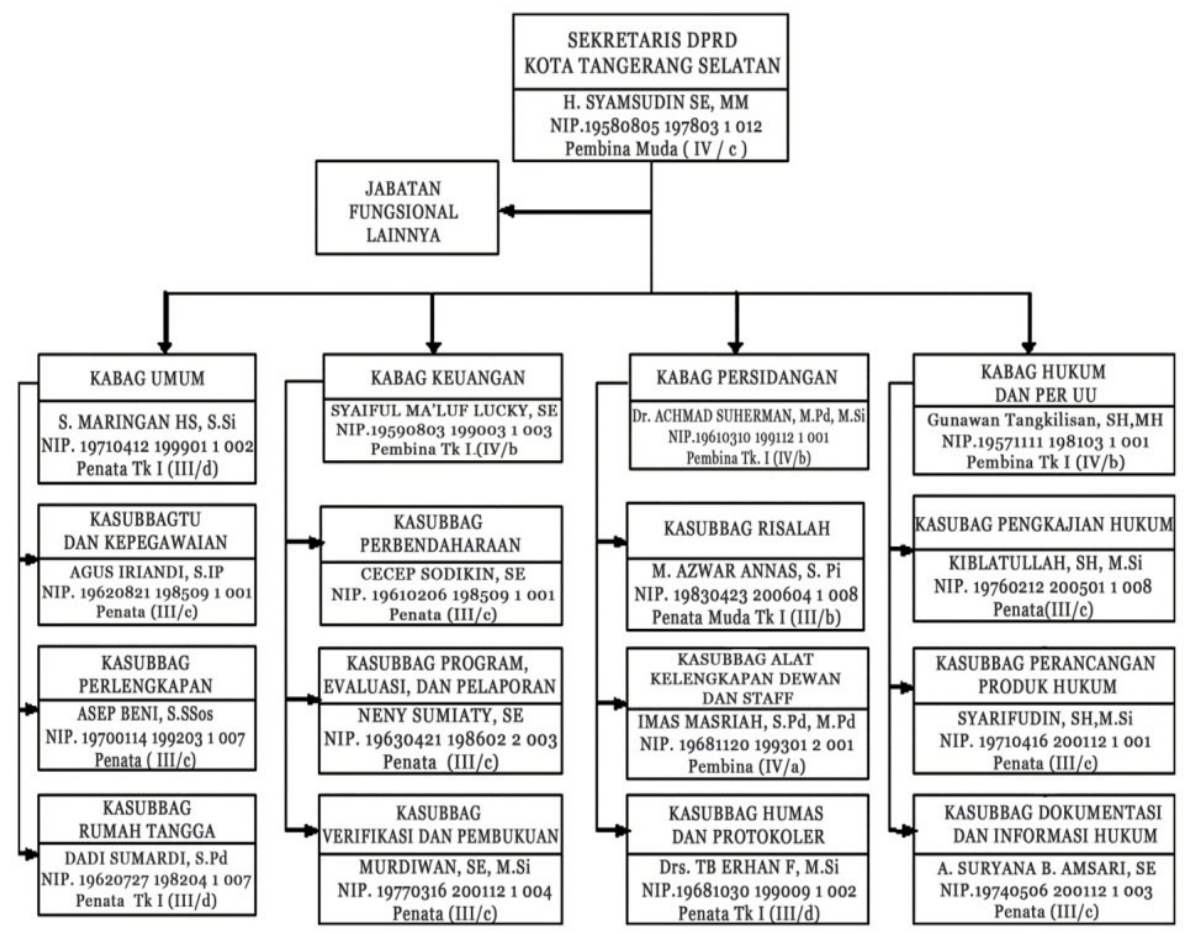

\section{Pembahasan dan Hasil}

Menguraikan tentang sejumlah data dan fakta tentang perusahan dengan cara praktek kerja lapangan yang dilakukan selama satu bulan terhitung dari tanggal 1 april sampai 30 april 2014 pada sekretariat DPRD kota tangerang selatan untuk dapat mengetahui dunia kerja secara nyata, mengetahui bagaimana peran seorang Keprotokolan dalam Menerima tamu Kunjungan kerja, adapun tugas yang dilakukan selama praktek kerja lapangan yaitu membantu protokol dalam mempersiapkan apa saja yang dibutuhkan dalam 
menerima tamu kunjungan kerja, serta tahap-tahap yang dilakukan sebelum menyepakati kunjungan kerja dari Instansi/Organisasi sebagai berikut :

a. Pihak DPRD menerima surat Kunjungan Kerja dari Instansi lain via fax.

b. Kemudian surat diberikan kepada Bapak Sekwan (Sekretaris Dewan) untuk di disposisi ke bagian masing-masing dan diterima atau tidaknya Kunjungan sesuai jadwal.

c. Apabila diterima sesuai jadwal, pihak keprotokolan akan mengkonfirmasi kembali Instansi yang akan berkunjung mengenai apa yang akan dibahas dan berapa jumlah orang yang akan berkunjung.

d. Pihak Keprotokolan mengkoordinasi dewan yang akan menerima sesuai jadwal.

e. Persiapan yang dilakukan keprotokolan ialah menyiapkan ruangan yang akan digunakan untuk menerima kunjungan kerja, lalu menata ruangan tersebut mulai dari tata letak meja, jumlah kursi dan snack

f. Keprotokolan harus mengkoordinasi kembali Dewan yang akan menerima kunjungan kerja.

g. Keprotokolan mempersilahkan tamu ke tempat yang sudah disediakan dan menghubungi Dewan agar segera menerima karna tamu Kunjungan kerja sudah datang.

h. Pihak DPRD Kota Tangerang Selatan meminta tanda tangan dan stempel sebagai bukti SPJ bahwa Instansi tersebut telah datang.

i. Keprotokolan mendokumentasikan Kunjungan dari Instansi tersebut dan pemberian plakat.

\section{Kesimpulan}

Berdasarkan hal-hal yang telah diuraikan sebelumnya dan berdasarkan hasil kerja lapangan yang telah penulis lakukan maka pada bab terakhir ini penulis akan menarik kesimpulan dari keseluruhan laporan masa akhir yaitu

1. Pada dasarnya Keprotokolan dalam menerima tamu kunjungan kerja di SEKRETARIAT DPRD KOTA TANGERANG SELATAN masih memiliki beberapa kendala namun beberapa kendala atau masalah tersebut masih diperbaiki oleh beberapa solusi yang telah dikemukakan dari beberapa sumber

2. Keprotokolan merupakan salah satu kegiatan penting dan bisa membawa nama baik suatu instansi/organisasi. Antara keprotokolan dengan pers harus 
mempunyai hubungan yang baik, karena Keprotokolan yang mempersiapkan pertemuan antara pimpinan untuk mengadakan konferensi pers.

3. Keprotokolan harus mendokumentasikan setiap acara yang diadakan oleh Instansi baik di dalam atau di luar kota.

4. Keprotokolan di Sekretariat DPRD Kota Tangerang Selatan kurang efektif, karna kurangnya ruangan yang disediakan.

\section{E. Saran}

Berdasarkan uraian diatas penulis mencoba untuk mengeluarkan beberapa saran yang mungkin kiranya dapat diterima atau bermanfaat sebagai bahan untuk kemajuan Keprotokolan dalam bekerja, untuk saran tersebut kami sampaikan sebagai berikut :

1. Kepada pihak Instansi atau Perusahaan

a. Perlu lebih memperbaiki tata cara dalam menerima tamu kunjungan kerja sehingga lebih terarah, maka dari itu seorang protokol bukan hanya mempelajari tetapi juga harus memperhatikan aturan-aturan yang berlaku di Instansi/Organisasi tersebut serta leih meningkatkan kinerja keprotokolan di Sekretariat DPRD Kota Tangerang Selatan.

b. Seorang Protokol harus lebih bertanggung jawab terhadap pekerjaannya.

2. Kepada pihak Universitas Pamulang perlu menjalin hubungan baik dengan Instansi lain agar mahasiswa dapat dengan mudah ditempatkan untuk pelaksanaan magang dan perekrutan untuk nantinya dapat menjadi pekerja atau karyawan di perusahaan.

\section{DAFTAR PUSTAKA}

Mulyati, A, Dra. Keprotokolan Pusat Pengembangan Penataran Guru Kejuruan, Jakarta, 2001

Suminar, Ratna, Dra. Pengetahuan Sekretaris, 2012

Olli, Helena, Public Speaking, PT Indeks, Jakarta 2012

Lawalata, Caroline, Panduang Lengkap Pekerjaan Sekretaris,Jakarta, 2012

Wiryandari, Rosita, Fungsi Keprotokolan, Jakarta, 2007 
